\title{
Determination of Lead and Cadmium in Sugar and Cement Industry Effluents of North Karnataka
}

Vinayak Balappanavar ${ }^{*}$, Shivalingayya Hiremath, Shivanand Mathapati. Danesh Hiremath,

M.S.Yadawe, U.S Pujeri, A.S.Pujar ${ }^{*}$ and S.C.Hiremath

S.B.Arts and K.C.P.Science College P.G. Department of Chemistry, Bijapur Karnataka India

Sihiremath555@gmail.com, vinayakabalappanavar@gmail.com

\section{Abstract}

The aim of this study is to assess the extent of lead and cadmium contamination in effluent released from sugar and Cement Industries in north Karnataka. Physicochemical analysis of effluent reveals that the concentration of lead $(0.05 \mathrm{mg} / \mathrm{l})$ and cadmium $(0.01 \mathrm{mg} / \mathrm{l})$ is greater than the permissible limit. The effluent as well as contaminated water is extensively used for the irrigation and drinking purposes in the surrounding areas. Several studies of heavy metal constituents in molasses and other sugars have been conducted.

\section{Council for Innovative Research}

Peer Review Research Publishing System

Journal: Journal of Advances in Chemistry

Vol. 10, No. 3

editorjaconline@gmail.com

www.cirjac.com 


\section{Introduction}

Heavy metals such as lead, cadmium and mercury are rapidly increasing continuously to an alarming level, particularly in rivers and near shore waters where industrial wastes are being discharged. They tend to concentrate in all matrices in the environment [1]. Mining, pouring, casting, processing, and metals use have led to their dispersion into the general environment. Ingestion of food and beverages contaminated with heavy metals can impair the health of the general population [2]. The problem of environmental pollution due to toxic metals has begun to cause concern now in most major metropolitan cities. The toxic heavy metals entering the ecosystem may lead to geoaccumulation, bioaccumulation and biomagnifications. Heavy metals like iron, copper, zinc, nickel and other trace elements are important for proper functioning of biological systems and their deficiency or excess could lead to number of disorders[3].

Food chain contamination by heavy metals has become a burning issue in recent years because of their potential accumulation in biosystems through contaminated water, soil and air. Therefore, a better understanding of heavy metal sources, their accumulation in the soil and the effect of their presence in water and soil on plant systems seem to be particularly important issue of present day research on risk assessments [4]. The main sources of heavy metals to vegetables crops are their growth media( soil, air, nutrient solutions) from which these are taken up by the roots or foliage. Most of our water resources are gradually becoming polluted due to the addition of foreign materials from the surroundings. These include organic matter of plant and animal origin, land surface washing and industrial and sewage effluent [5]. Rapid urbanization and industrialization with improper environmental planning often lead to discharge of industrial and sewage effluent into water body. It has been reported that sewage effluents of municipal origin contain appreciable amount of major essential plant nutrients and therefore the fertility levels of soil are improved considerably under sewage irrigation crop field [4]. However, studies on the water of Vasai Creek, Maharastra reveal that the presence of toxic heavy metals like iron, lead, and mercury residue soil fertility and agricultural output [6].

Heavy metals such as lead, cadmium and mercury are rapidly increasing continuously to an alarming level, particularly in rivers and near shore waters where industrial wastes are being discharged. They tend to concentrate in all matrices in the environment [7]. Mining, pouring, casting, processing and metals use led to their dispersion into the general environment. Ingestion of food and beverages contaminated with heavy metals can impair the health of the general population [8]. Lead and cadmium are trace elements which, because they serve no known useful purpose in the body of any living organism, have serious and varied adverse effects. As a result, lead and cadmium may accumulate in particular organs of body. In order to prevent harmful exposure awareness of sources and uses, modes of entry into the body, toxic effects and safe limits must be established.

Cadmium affects various organs such as bones, brain, kidney and nervous system. Research on the long term toxic effects and accumulation patterns of cadmium in fish [9,10], also lend support to the effects on humans $[11,12]$.Cadmium toxicity towards marine and fresh water organisms is also well known. It is potential health hazard due to its presence in urban atmosphere and cigarette smoke [13]. The permissible limit of cadmium in drinking water is $0.05 \mathrm{mg} / \mathrm{l}$ according to EPA [14].

\section{Material and methods}

Water samples were analyzed according to the standard APHA method[15].Shimadzu (Kyoto, Japan) (Model 1601PC) double beam UV/VIS recording spectrophotometer and the $\mathrm{pH}$ and electrical conductivity (EC) of the water samples were tested using pre-calibrated $\mathrm{pH}$ and conductivity.

\section{Reagents and Solutions}

All the chemicals used were of analytical-reagent grade or the highest purity available. Doubly distilled deionized water, which is non-absorbent under ultraviolet radiation, was used throughout. Glass vessels were cleaned by soaking in acidified solutions of $\mathrm{KMnO}_{4}$ or $\mathrm{K}_{2} \mathrm{Cr}_{2} \mathrm{O}_{7}$ followed by washing with nitric acid $(1+1)$ and rinsed several times with highpurity de-ionized water. Stock solutions and environmental water samples (1000 $\mathrm{mL}$ each) were kept in polypropylene bottles containing $1 \mathrm{~mL}$ of concentrated $\mathrm{HNO}_{3}$ 
Table.1 Pysicochemical, lead and cadmium concentrations in sugar and cement industry effluent

\begin{tabular}{|c|c|c|c|c|c|}
\hline S.NO & Industry & $\mathrm{pH}$ & $\begin{array}{c}\text { EC } \\
\mu \mathrm{mhos} / \mathrm{cm}\end{array}$ & $\begin{array}{l}\text { Lead } \\
\mathrm{mg} / \mathrm{L}\end{array}$ & $\begin{array}{c}\text { Cadmium } \\
\text { mg/L }\end{array}$ \\
\hline 1 & $\begin{array}{l}\text { Jamakhandi } \\
\text { Sugar }\end{array}$ & 5.8 & 161 & 3.3 & 1.0 \\
\hline 2 & $\begin{array}{l}\text { Kagawad } \\
\text { sugar }\end{array}$ & 2.1 & 22 & 8.0 & 1.3 \\
\hline 3 & KempwadETP & 6.0 & 545 & 1.45 & 0.90 \\
\hline 4 & $\begin{array}{l}\text { Jamakhandi } \\
\text { sugar }\end{array}$ & 6.9 & 89 & 0.3 & 1.0 \\
\hline 5 & Kempawad I & 5.7 & 74 & 0.6 & Nil \\
\hline 6 & Cement & 6.5 & 177 & 0.20 & 0.35 \\
\hline 7 & Nirani Sugar & 6.2 & 388 & 1.2 & Nil \\
\hline 8 & Renuka sugar & 4.9 & 686 & 0.85 & Nil \\
\hline 9 & $\begin{array}{l}\text { Sanagur } \\
\text { sugar }\end{array}$ & 3.3 & 60 & 2.9 & 0.5 \\
\hline 10 & Ugar sugar & 5.2 & 180 & Nil & Nil \\
\hline 11 & $\begin{array}{l}\text { Sameerwadi } \\
\text { sugar }\end{array}$ & 1.2 & 60 & 1.15 & Nil \\
\hline 12 & Nandi sugar & 2.6 & 250 & 5.70 & 0.90 \\
\hline
\end{tabular}

\section{Result and discussion}

The $\mathrm{pH}$ of the water samples measured at different sampling station ranged from 2.1 to 6.9 indicating that all water samples are acidic in nature. EC of the water ranged from22 to $686 \mathrm{micro} \mathrm{mhos} / \mathrm{cm}$. Average three values of Lead concentrations ranged from 0.20 to $8.0 \mathrm{mg} / \mathrm{l}$. According to Indian standard drinking water specification 1991, highest desirable limit of lead in drinking water is $0.05 \mathrm{ppm}$ and no relaxation for maximum permissible limit. The mean lead content of $8.00 \mathrm{mg} / \mathrm{l}$ was about ten times the WHO permissible limit of $0.05 \mu \mathrm{g} / \mathrm{dl}(0.5 \mathrm{ppb})$ of lead in drinking water (WHO, 1998), Provisional tolerable weekly intake of $25 \mu \mathrm{g} / \mathrm{l}$ lead per $\mathrm{kg}$ body wt or $93.5 \mu \mathrm{g} / \mathrm{kg}$ body wt/day for all age group was established (WHO 1993). Lead is a cumulative general poison and associated with several health hazards like anemia [16]. Since the residents totally depend on such water for all their daily domestic needs, long-term accumulation of lead in the body via oral ingestion and dermal absorption is a possibility [17]. The range of cadmium concentration in industrialwater ranged from 0.35 to $1.35 \mathrm{mg} / \mathrm{l}$. Ingestion of cadmium causes immediate poisoning and damage to the liver and kidneys, including renal failure which is fatal. Cadmium affects bones as well, making them soft and to lose density. This causes pain in the joints and in the back. The risk of fracture increases alarmingly. In extreme cases, mere bodyweight can cause fractures. The EPA has discovered that cadmium has high potential to cause health effect like nausea, vomiting, diarrhea, muscle cramps, salivation, sensory disturbances, liver injury, convulsions, shock and renal failure in short period of time. In a lifetime exposure to cadmium at levels exceed $0.005 \mathrm{mg} / \mathrm{L}$ can cause kidney, liver, bone and blood damage [18].

\section{Conclusion}

In this paper a simple sensitive, selective and inexpensive method using Cd Alizarin Red S complex was developed for the determination of cadmium in industrial effluents. For the determination of lead a sensitive and selective method is used by by Alizarin yellow reagent. Lead and cadmium content in most of the water samples are above the permissible limit of Indian standards.

\section{Acknowledgements}

Authors are thankful to management authority, Principal and staff of Chemistry departs of S.B.Arts and K.C.P.Science College Bijapur, Karnataka India. 


\section{References}

1. R. K. Srivastav, S. K. Gupta, K. D. P. Nigam and P. Vasudevan, "Treatment of Chromium and Nickel in Wastewater by Using Aquatic Plants," Water Research, Vol. 28, No. 7, July 1994, pp. 1631-1638.

2. P. J. Apostoli, "Elements in Environmental and Occupa- tional Medicine," Journal of Chromatography B, Vol. 778, No. 1, October 2002, pp. 63-97'

3. Ward N.I, Environmental analytical Chemistryin trace elements( eds Fifield.F.W and Haines P.J ) Blackie Academic and professional, U.K 1995, pp.320-328.

4. Rajeshkumar,Sharma, Madhulika.Agarawwal and Marshall.F.M., Effects of waste water irrigation on heavy metal accumulation in soil and plant. Paper presented at a National Seminar, Bangalore University, Bangalore 2004 Abst no $7 \mathrm{p}-8$.

5. Karnataka State Pollution Control Board, Water Quality monitoring of lakes in and around Bangalore city Bangalore,2002,vol2. P.1-8.

6. Lokhande.R.S, and Kelkar N, Studies on heavy metals in water of Vasai Creck, Maharastra, India J.Environ.Protect,1999,19,664-668.

7. R.K.Srivastava, S.K.Gupta,K.D.P.Nigam and P Vasudevan. "Treatment of Chromium and Nickel in Waste Water by using Aquatic Plants, Water Research, vol.28.No7,July 1994,pp.1631-1638.

8. P.J.Apostoli. "Elements in Environmental and Occupational Medicine "Journal of Chromatography.B.Vol778.No.1.October 2002 pp.63-97

9. Suresh A,.B.Sivaramkrishna and K Radhakrishnaiah., Patterns of cadmium Accumulation in the organs of Fry and Fingerlings of Freshwater Fish(Cypririus Carpio) Following cadmium Exposure" Chemosphere,vol.26.No.5,pp.945-953. 1993.

10. Nriagu.J.O and J.B.Sprague, "Effects of Cadmium on Freshwater Fish from Cadmium in the Aquatic Environment" John Wiley and Sons, New York.N.Y.pp.139-169.1987.

11. ATSDR, 2008,Draft Toxicological Profile for Cadmium, Agency for toxic substances and Diseases Registry, US Public Health Services. Atlanta,GA USA.

12. ATSDR 1993, Toxicological profile for Cadmium Agency for Toxic substances and Diseses Registry US Public Health Services, Atlanta GA USA.

13. B.Venugopal and T.D.Luckey(1979).Metal Toxicity in Mammals-2, Plemium Press,New York.76.

14. Second Annual Report on Carcinogens ( Dec 19810 Environmental Protection Agency, NTP,81-143.

15. American Public Health Association (APHA) 2005,Standard Methods for the Examination of Water and Wastewater.

16. Moore MR. Haematological effects of lead. Sci Total Environ. 1988;71:419-31.

17. Florence TM, Stauder JL, Dale LS, Henderson D, Izard BE, Belbin K (2003). Skin Absorption of Ionic Lead Compounds. J. Aust. College Nutr. Environ. Med. 15(2): 11-12.

18. Ideris, Z. (2008). Study of the Quality of Commercial Bottled Mineral Waters in Malaysia (Masters dissertation, University Malaya, 2008). 